\title{
SYNTHESIS AND FIELD TEST OF A PHEROMONE ANALOG OF CHILECOMADIA VALDIVIANA
}

\author{
HEIDY HERRERA $A^{a}$, WILSON BARROS-PARADA $A^{b, c}$, M. FERNANDA FLORES ${ }^{a}$, \\ EDUARDO FUENTES-CONTRERAS ${ }^{b}$, JAN BERGMANN ${ }^{a, *}$
}

aInstituto de Química, Facultad de Ciencias, Pontificia Universidad Católica de Valparaíso, Valparaíso, Chile

${ }^{b}$ Millennium Nucleus Center in Molecular Ecology and Evolutionary Applications in the Agroecosystems (CEM), Facultad de Ciencias Agrarias, Universidad de Talca, Talca, Chile

${ }^{c}$ Escuela de Agronomía, Pontificia Universidad Católica de Valparaíso, Casilla 4-D, Quillota, Chile

\begin{abstract}
The main pheromone component of Chilecomadia valdiviana has recently been reported to be (7Z,10Z)-7,10-hexadecadienal. The synthesis of a structural analog, (5Z,8Z)-5,8-tetradecadienyl formate is reported. The pheromone analog was not attractive to male $C$. valdiviana in the field, nor did it antagonize attraction of males to the pheromone compound.
\end{abstract}

Keywords: Chilecomadia valdiviana, formate, pheromone analog.

\section{INTRODUCTION}

Pheromones are natural compounds released by an individual, which elicit a response, either behavioral or physiological, in another individual of the same species. Since the first identification of a pheromone in 1959 [1], the structures of over 1,500 insect pheromones have been elucidated [2], and in many cases pheromone-based methods have been successfully integrated in pest management programs [3]. Research in insect olfaction and the development of pest control strategies include the study of the biological activity of anthropogenic compounds that are structurally similar to the naturally occurring pheromones. In this context, some of the most common structural modifications of the natural pheromone compounds are alterations of the carbon chain (elongation, shortening, alteration of multiple bonds), changes of the polar functional group, and the introduction of isosteric atoms or isotopes [4]. The biological activity of the modified compounds varies greatly, and the analogs may be attractants, antagonists, or show no biological activity at all. In cases where the pheromone analog exhibits adequate biological activity and is less costly to prepare and/or more stable than the natural pheromone, it may replace the pheromone in pest control methods.

The carpenterworm, Chilecomadia valdiviana (Philippi) (Lepidoptera:
Cossidae), is a native moth from Chile and Argentina whose larval stages have long been known to feed on the wood of native species of trees and bushes [58]. Over the last two decades, the insect has also been detected in economically important forest and fruit tree crops such as eucalyptus, avocado, apple, cherry, olive, pear and others [9-13]. Besides direct and indirect damage to the tree, the presence of $C$. valdiviana also affects export of wood products because of quarantine restrictions in destination countries [14]. The main pheromone component produced by females is the unsaturated aldehyde $(7 Z, 10 Z)-7,10$ hexadecadienal (Z7,Z10-16:Ald), together with small amounts of structurally related compounds [15], and it was shown that the Z7,Z10-16:Ald alone is responsible for the long-range attraction of males to the pheromone source [16].

Because aldehydes are susceptible to degradation, particularly under field conditions, and the degradation products are usually not biologically active, we synthesized an analog, (5Z,8Z)-5,8-tetradecadienyl formate (Z5,Z8-14:Fo), in which the $\alpha$-methylene group is formally replaced by an oxygen atom (Fig. 1), and studied its biological activity in field tests. We have chosen this modification because formates have shown to successfully mimic aldehyde pheromones [17-19], and because it has been suggested that this functional group is more stable than the formyl group of an unsaturated aldehyde [19].

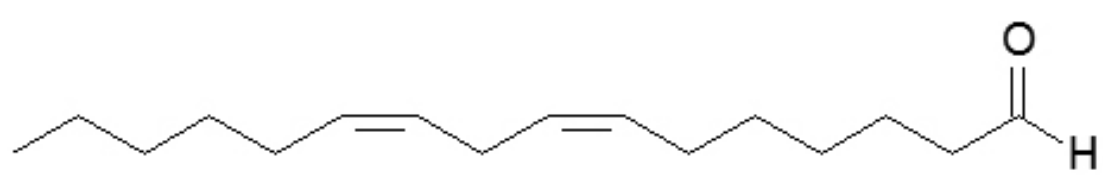

\section{Z7,Z10-16:Ald}

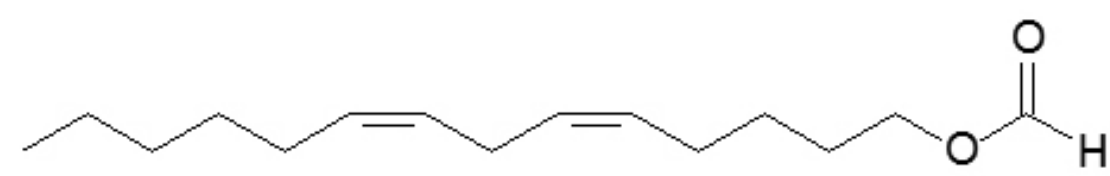

\section{Z5,Z8-14:Fo}

Figure 1: Structures of (7Z,10Z)-7,10-hexadecadienal (Z7,Z10-16:Ald) and (5Z,8Z)-5,8tetradecadienyl formate (Z5,Z8-14:Fo) 


\section{EXPERIMENTAL}

2.1. General synthetic procedures

All reagents were purchased from Merck (Darmstadt, Germany) or SigmaAldrich (St. Louis, MO, USA) and used as received. Solvents were purchased from Merck and dried according to standard procedures if necessary. Syntheses involving air- or moisture-sensitive materials were carried out under inert atmosphere in dried glassware. Silica gel $60(0.063-0.200 \mathrm{~mm}$, Merck) was used for column chromatography. Nuclear magnetic resonance (NMR) data were acquired on a Bruker Fourier 300 spectrometer $\left(300 \mathrm{MHz}\right.$ for ${ }^{1} \mathrm{H}$ and $75 \mathrm{MHz}$ for ${ }^{13} \mathrm{C}$ ), and chemical shifts $(\delta)$ are reported in ppm relative to the internal standard tetramethylsilane. Coupling constants $J$ are given in Hz.

2.2. Synthesis of (5Z,8Z)-5,8-tetradecadienyl formate (Fig. 2)

Synthesis of 5-(2'-tetrahydropyranyloxy)pentan-1-ol (2)

To a solution of $5.00 \mathrm{~g}$ (48.1 mmol) 1,5-pentanediol (1) and $110 \mathrm{mg}$ p-toluenesulfonic acid in $80 \mathrm{~mL}$ dry dichloromethane was added $4.04 \mathrm{~g}$ (48,1 mmol) 3,4-dihydro- $2 \mathrm{H}$-pyran at $0^{\circ} \mathrm{C}$. After $30 \mathrm{~min}$ stirring at room temperature, $100 \mathrm{~mL}$ hexane and $30 \mathrm{~mL}$ sat. $\mathrm{NaHCO}_{3}$ were added and stirring was continued for another $10 \mathrm{~min}$. The phases were separated and the aqueous phase was extracted three times with $50 \mathrm{~mL}$ hexane-ethyl acetate $(1: 1)$. The combined organic phases were dried with $\mathrm{MgSO}_{4}$ and concentrated. The crude product was purified by column chromatography (hexane-ethyl acetate $4: 1$ ) to yield $3.80 \mathrm{~g}(20.2 \mathrm{mmol}, 42 \%)$ of a colorless oil. ${ }^{1} \mathrm{H} \mathrm{NMR}\left(\mathrm{CDCl}_{3}\right): \delta=1.21$ $1.90(\mathrm{~m}, 12 \mathrm{H}), 3.32-3.90(\mathrm{~m}, 6 \mathrm{H}), 4.60(\mathrm{t}, 1 \mathrm{H}, J=3.5 \mathrm{~Hz}) .{ }^{13} \mathrm{C} \mathrm{NMR}\left(\mathrm{CDCl}_{3}\right)$ : $19.7,22.5,25.5,29.4,30.7,32.5,62.4,62.8,67.5,98.9$

\section{Synthesis of 5-(2'-tetrahydropyranyloxy)pentanal (3)}

Pyridinium dichromate $(5.60 \mathrm{~g}, 14.9 \mathrm{mmol})$ and $\mathrm{MgSO}_{4}(0.5 \mathrm{~g})$ were added to a solution of $2(2.80 \mathrm{~g}, 14.9 \mathrm{mmol})$ in $100 \mathrm{~mL}$ dry dichloromethane, and the mixture was stirred overnight at room temperature. Hexane $(30 \mathrm{~mL})$ was added and the mixture was filtered. The filtrate was concentrated, water (50 $\mathrm{mL})$ was added, and the mixture was extracted with diethyl ether $(3 \times 50 \mathrm{~mL})$. The combined organic phases were dried with $\mathrm{MgSO}_{4}$ and concentrated. The crude product was purified by column chromatography (hexane-ethyl acetate $7: 1)$ to yield $2.50 \mathrm{~g}(13.4 \mathrm{mmol}, 93 \%)$ of a colorless oil. ${ }^{1} \mathrm{H} \mathrm{NMR}\left(\mathrm{CDCl}_{3}\right): \delta=$ $1.51-1.70(\mathrm{~m}, 10 \mathrm{H}), 2.50(\mathrm{~m}, 2 \mathrm{H}), 3.41-3.70(\mathrm{~m}, 2 \mathrm{H}), 3.72-3.80(\mathrm{~m}, 2 \mathrm{H}), 4.60$ $(\mathrm{t}, 1 \mathrm{H}, \mathrm{J}=3.5 \mathrm{~Hz}), 9.80(\mathrm{t}, 1 \mathrm{H}, J=1.8) .{ }^{13} \mathrm{C} \mathrm{NMR}\left(\mathrm{CDCl}_{3}\right): 19.0,19.7,25.4$ $29.1,31.6,43.6,62.4,67.0,98.9,202.5$

Synthesis of (Z)-1-bromo-3-nonene (5)

A solution of $3.68 \mathrm{~g}(14.0 \mathrm{mmol})$ triphenylphosphine in 100 dry dichloromethane was cooled to $0{ }^{\circ} \mathrm{C}$ and $0.71 \mathrm{~mL}(14.0 \mathrm{mmol})$ bromine was added dropwise. After addition of $1.99 \mathrm{~g}(14.0 \mathrm{mmol})(Z)-3$-nonen-1-ol (4), the mixture was warmed to room temperature and stirred for $2 \mathrm{~h}$. Hexane $(100 \mathrm{~mL})$ and sat. $\mathrm{NaHCO}_{3}(100 \mathrm{~mL})$ were added, the phases were separated, and the aqueous phase was extracted twice with hexane. The combined organic phases were washed with water and brine, dried over $\mathrm{MgSO}_{4}$, and concentrated. The precipitate was filtered off, washed with hexane, and the filtrate was again concentrated. The residue was purified by column chromatography (hexane) Yield $2.58 \mathrm{~g}(12.6 \mathrm{mmol}, 90 \%)$.

${ }^{1} \mathrm{H}$ NMR $\left(\mathrm{CDCl}_{3}\right): \delta=0.90(\mathrm{t}, 3 \mathrm{H}, J=6.7), 1.22-1.45(\mathrm{~m}, 6 \mathrm{H}), 1.99-2.11$ (m, 2H), 2.58-2.68 (m, 2H), $3.18(\mathrm{t}, 2 \mathrm{H}, J=7.3), 5.31-5.42(\mathrm{~m}, 1 \mathrm{H}), 5.49-5.60$ $(\mathrm{m}, 1 \mathrm{H}) .{ }^{13} \mathrm{C} \mathrm{NMR}\left(\mathrm{CDCl}_{3}\right): \delta=14.0,22.6,27.4,29.2,30.9,31.5,32.5,125.7$, 133.2

Synthesis of (Z)-3-nonenyl triphenylphosphonium bromide (6)

A solution of $1.80 \mathrm{~g}(8.78 \mathrm{mmol}) \mathbf{5}$ and $2.30 \mathrm{~g}(8.78 \mathrm{mmol})$ triphenylphosphine in $60 \mathrm{~mL}$ acetonitrile was refluxed for $72 \mathrm{~h}$. After cooling, the solvent was removed and the residue was purified by column chromatography (dichloromethane-methanol 2:1). Yield: $3.05 \mathrm{~g}(74 \%)$ ).

${ }^{1} \mathrm{H}$ NMR (CD OD): $\delta=0.88(\mathrm{t}, 3 \mathrm{H}, J=6.6), 1.15-1.37(\mathrm{~m}, 6 \mathrm{H}), 1.85-1.95$ (m, 2H), 2.39-2.53 (m, 2H), 3.50-3.62 (m, 2H), 5.44-5.59 (m, 2H), 7.76-7.97 $(\mathrm{m}, 15 \mathrm{H}) .{ }^{13} \mathrm{C}$ NMR $\left(75 \mathrm{MHz}, \mathrm{CD}_{3} \mathrm{OD}\right): \delta 13.0,19.9,21.2,21.9,22.1,26.8$, $28.7,31.2,117.9,119.0,125.7,125.9,132.5,130.3,130.1,133.4,133.6,134.9$, 135.0

Synthesis of 2-((5Z,8Z)-5,8-tetradecadienyloxy)tetrahydropyran (7)

A $1.0 \mathrm{M}$ solution of sodium bis(trimethylsilyl)amide in THF $(4.0 \mathrm{~mL}, 4.0$ mmol) was added dropwise to a suspension of $1.50 \mathrm{~g}(\mathrm{mmol}) 6$ in $80 \mathrm{~mL}$ dry tetrahydrofuran at $-20{ }^{\circ} \mathrm{C}$. After $30 \mathrm{~min}$, the resulting red solution was cooled to $-78{ }^{\circ} \mathrm{C}$ and $0.85 \mathrm{~g}(3.90 \mathrm{mmol}) 3$ were added. After $30 \mathrm{~min}$, the mixture was allowed to warm to room temperature and was stirred for another $1.5 \mathrm{~h}$, after which it was poured on an ice-water mixture. Diethyl ether was added, the phases separated, and the aqueous phase was extracted twice with ether. The combined organic phases were washed with water and brine, dried over $\mathrm{MgSO}$ and concentrated. The white precipitate was filtered and washed with ether. The filtrate was again concentrated and the residue was purified by column chromatography (hexane-ethyl acetate 7:1) on silver nitrate-impregnated silica. Yield: $0.45 \mathrm{~g}(1.53 \mathrm{mmol}, 39 \%) .{ }^{1} \mathrm{H} \mathrm{NMR}\left(\mathrm{CDCl}_{3}\right): \delta 0.91(\mathrm{t}, 3 \mathrm{H}, J=6.7)$, $1.23-1.45(\mathrm{~m}, 14 \mathrm{H}), 1.48-1.66(\mathrm{~m}, 6 \mathrm{H}), 2.00-2.12(\mathrm{~m}, 4 \mathrm{H}), 2.75-2.84(\mathrm{~m}, 2 \mathrm{H})$ $3.40(\mathrm{dt}, 1 \mathrm{H}, \mathrm{J}=6.6,9.6), 3.47-3.56(\mathrm{~m}, 1 \mathrm{H}), 3.75(\mathrm{dt}, 1 \mathrm{H}, J=6.8,9.5), 3.83$ $3.94(\mathrm{~m}, 1 \mathrm{H}), 4.56-4.62(\mathrm{~m}, 1 \mathrm{H}), 5.28-5.47(\mathrm{~m}, 2 \mathrm{H}) .{ }^{13} \mathrm{C} \mathrm{NMR}\left(\mathrm{CDCl}_{3}\right): 14.1$ $19.7,22.6,25.5,25.6,26.3,27.0,27.2,29.3,29.4,30.8,31.5,62.3,67.5,98.8$, $127.9,128.8,129.8,130.3$

Synthesis of (5Z,8Z)-5,8-tetradecadien-1-ol (8)

To a solution of $7(0.45 \mathrm{~g}, 1.53 \mathrm{mmol})$ in $20 \mathrm{~mL}$ methanol was added a catalytic amount of p-toluenesulfonic acid. After $2 \mathrm{~h}$ stirring at room temperature, the solvent was removed and the residue was dissolved in dichloromethane. The solution was washed with sat. NaHCO3, dried over $\mathrm{MgSO} 4$, and concentrated. The residue was purified by column chromatography (hexane-ethyl acetate 5:1). Yield $300 \mathrm{mg}(1.43 \mathrm{mmol}, 93 \%)$. ${ }^{1} \mathrm{H} \mathrm{NMR}\left(\mathrm{CDCl}_{3}\right)$ : $\delta=0.90(\mathrm{t}, 3 \mathrm{H}, J=7.1), 1.23-1.47(\mathrm{~m}, 8 \mathrm{H}), 1.52-1.65(\mathrm{~m}, 2 \mathrm{H}), 1.98-2.16$ $(\mathrm{m}, 4 \mathrm{H}), 2.74-2.84(\mathrm{~m}, 2 \mathrm{H}), 3.61-3.71(\mathrm{~m}, 2 \mathrm{H}), 5.28-5.47(\mathrm{~m}, 4 \mathrm{H}) .{ }^{13} \mathrm{C}$ NMR $\left(\mathrm{CDCl}_{3}\right): 14.1,22.6,25.6,25.8,26.9,27.2,29.3,31.5,32.4,62.9,127.8,128.5$, $129.6,130.3$

Synthesis of (5Z,8Z)-5,8-tetradecadienyl formate

Dicyclohexylcarbodiimide $(0.38 \mathrm{~g}, 1.84 \mathrm{mmol})$ and a catalytic amount of 4-(dimethylamino)pyridine were added to a solution of formic acid (85 $\mathrm{mg}, 1.85 \mathrm{mmol})$ in $6 \mathrm{~mL}$ dry dichloromethane. After addition of $300 \mathrm{mg}$ (1.43 $\mathrm{mmol}) \mathbf{8}$, the reaction mixture was stirred $4 \mathrm{~h}$ at room temperature. Dichloromethane $(15 \mathrm{~mL})$ was added, the solution was filtered, and the filtrate was washed with brine, dried over $\mathrm{MgSO}_{4}$, and concentrated. The residue was purified by column chromatography (hexane-ethyl acetate 9:1). Yield $330 \mathrm{mg}$ $(1.39 \mathrm{mmol}, 97 \%) .{ }^{1} \mathrm{H}$ NMR $\left(\mathrm{CDCl}_{3}\right): \delta=0.90(\mathrm{t}, 3 \mathrm{H}, J=6.8), 1.24-1.53(\mathrm{~m}$, $8 \mathrm{H}), 1.46-1.76(\mathrm{~m}, 2 \mathrm{H}), 2.00-2.20(\mathrm{~m}, 4 \mathrm{H}), 2.71-2.85(\mathrm{~m}, 2 \mathrm{H}), 4.19(\mathrm{t}, 2 \mathrm{H}, J=$ 6.6), 5.27-5.47 (m, 4H), 8.07 (s, 1H). ${ }^{13} \mathrm{C} \mathrm{NMR}\left(\mathrm{CDCl}_{3}\right): 14.1,22.6,25.6,25.8$, $26.7,27.2,28.1,29.3,31.5,63.9,127.7,128.8,129.2,130.3,161.1$

\subsection{Field tes}

The field test was carried out from September 28 until October 12, 2016 , in an apple orchard in Colbún Poniente ( $\left.35^{\circ} 43^{\prime} 12.99^{\prime \prime} \mathrm{S}, 71^{\circ} 27^{\prime} 33.59^{\prime \prime} \mathrm{W}\right)$ Traps consisted of 20 L-buckets filled with a saline solution as described earlier [15]. Lures containing synthetic compounds were prepared by loading white rubber septa (Sigma-Aldrich, catalog \#Z553905) with $100 \mu \mathrm{L}$ of an appropriate solution of Z7,Z10-16:Ald (synthesized as described in [15]) and/or Z5,Z814:Fo in hexane. Septa treated with $100 \mu \mathrm{L}$ of hexane were used as controls. The following treatments were used: (1) $300 \mathrm{mg} \mathrm{Z5,Z8-14:Fo,} \mathrm{(2)} 300 \mathrm{mg}$ Z7,Z10-16:Ald, (3) $300 \mathrm{mg} \mathrm{Z7,Z10-16:Ald} \mathrm{+} 300 \mathrm{mg}$ Z5,Z8-14:Fo, (4) control. For each treatment, 6 replicates were used, spatially arranged as a complete randomized block design. Traps were placed at 3.0-3.5 m height from the tree branches, evenly distributed on different orchard rows with a distance of 20-22 $\mathrm{m}$ between the traps. The captured moths were counted, sexed and removed from the traps at intervals of 7 days. Total male trap catches, expressed as individuals per trap and per day, were compared among treatments using a non-parametric Kruskal-Wallis test.

\section{RESULTS AND DISCUSSION}

3.1. Synthesis of ( $5 Z, 8 Z)$-5,8-tetradecadienyl formate

The synthesis of Z5,Z8-14:Fo is outlined in Fig. 2. 1,5-Pentanediol (1) was transformed to the mono-tetrahydropyranyl (THP) ether 2 by reaction with 3,4-dihydro-2H-pyran (DHP) in dichloromethane (DCM) [20], which was subsequently oxidized using pyridinium dichromate (PDC) to furnish aldehyde 3. This oxidation reagent was chosen because of its experimental simplicity and good yields [21]. In parallel, (Z)-3-nonen-1-ol (4) was brominated using the bromine-triphenylphosphine complex $\left(\mathrm{PPh}_{3}-\mathrm{Br}_{2}\right)$. Use of this reagent prevents undesired elimination and rearrangements, as well as undesired bromination of the double bond [22]. The resulting bromide 5 was transformed to the corresponding Wittig salt $\mathbf{6}$ in good yield by heating with triphenylphospine $\left(\mathrm{PPh}_{3}\right)$ in acetonitrile $(\mathrm{MeCN})$. Generation of the ylide from 6 using sodium bis(trimethylsilyl)amide $\left(\mathrm{NaN}\left(\mathrm{SiMe}_{3}\right)\right.$ ) in tetrahydrofuran (THF) and reaction with aldehyde 3 at $-78^{\circ} \mathrm{C}$ resulted in the formation of the protected $(Z, Z)$-dienol 7 [23]. Traces of the $(E, Z)$-isomer were separated by column chromatography on silver nitrate-impregnated silica gel. Acid-catalyzed deprotection in methanol $(\mathrm{MeOH})$ and subsequent esterification of alcohol 8 with formic acid catalyzed by dicyclohexylcarbodiimide (DCC) furnished the desired product Z5,Z8-14:Fo in good overall yield. 

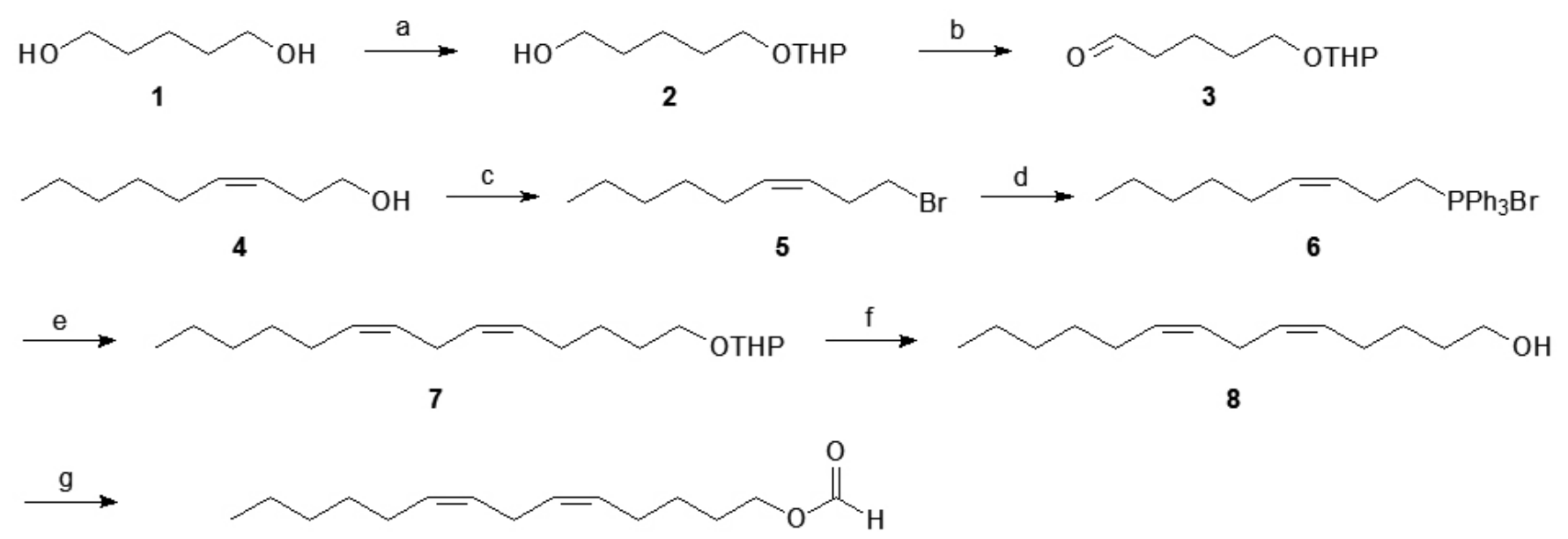

\section{Z5,Z8-14:Fo}

Figure 2: Synthesis of (5Z,8Z)-5,8-tetradecadienyl formate (Z5,Z8-14:Fo). Reagents and conditions: (a) DHP, DCM, $0{ }^{\circ} \mathrm{C}$; (b) $\mathrm{PDC}, \mathrm{DCM}$; (c) $\mathrm{PPh}-\mathrm{Br}_{2}$, DCM; (d) $\mathrm{PPh}_{3}, \mathrm{MeCN}$, reflux; (e) $\mathrm{NaN}\left(\mathrm{SiMe}_{3}\right)_{2}, \mathrm{THF}, 3,-78^{\circ} \mathrm{C}$; (f) $\mathrm{H}^{+}, \mathrm{MeOH}$; (g) $\mathrm{HCOOH}, \mathrm{DCC}$. Abbreviations are explained in the text.

\subsection{Field test}

No males were attracted to traps baited with the pheromone analog Z5,Z814:Fo alone (Table 1, entry 1). Furthermore, the number of males caught in traps baited with a 1:1 mixture of Z7,Z10-16:Ald and Z5,Z8-14:Fo did not differ from traps containing Z7,Z10-16:Ald only (Table 1, entries 2 and 3). These results indicate that Z5,Z8-14:Fo is not attractive to males, nor does it inhibit or synergize the attraction of males to the pheromone.

Table 1: Captures of male C. valdiviana in traps baited with synthetic compounds.

\begin{tabular}{|c|c|c|}
\hline Entry & Treatment $^{\mathrm{a}}$ & $\begin{array}{c}\text { Males per trap per day } \\
(\text { mean } \pm \text { S.E. })^{\mathrm{b}}\end{array}$ \\
\hline 1 & Z5,Z8-14:Fo (300 mg) & $0 \mathrm{~b}$ \\
\hline 2 & Z7,Z10-16:Ald (300 mg) & $7.5 \pm 1.0 \mathrm{a}$ \\
\hline 3 & $\begin{array}{c}\text { Z7,Z10-16:Ald (300 mg) + Z5,Z8- } \\
\text { 14:Fo (300 mg) }\end{array}$ & $9.1 \pm 2.3 \mathrm{a}$ \\
\hline 4 & Control & $0 \mathrm{~b}$ \\
\hline & & $\begin{array}{c}H_{(3,24)}=19.7 \\
P \leq 0.001\end{array}$ \\
\hline
\end{tabular}

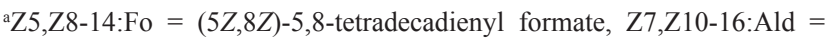
(7Z,10Z)-7,10-hexadecadienal

${ }^{b} \mathrm{~N}=6$. Means followed by different letters are significantly different according to Kruskal-Wallis test.

Other studies have shown that formate analogs are attractive to male moths. For example, $(7 Z, 9 E)-7,9,11$-dodecatrienyl formate is as attractive to males of the carob moth, Ectomyelois ceratonidae, as the pheromone $(9 Z, 11 E)$ 9,11,13-tetradecatrienal [19]. In Heliothis virescens, (Z)-9-tetradecenyl formate is capable of mimicking $(Z)$-11-hexadecenal, as 16:1 mixtures of either of the two compounds with (Z)-9-tetradecenal were equally attractive to males [17], and this formate analog has been shown to be an effective disruptant of pheromone communication in the field for this species [24]. A 10:1 mixture of $(E)$ - and (Z)-8-tetradecenyl formate was shown to be as attractive to males of the yellow peach moth, Dichocrocis punctiferalis, as a similar mixture of $(E)$ and $(Z)$-10-hexadecenal, the female-produced pheromone [18]. In contrast, formate analogs which contained a triple bond instead of a conjugated diene system were not attractive to males of the horse chestnut leafminer, Cameraria ohridella, but antagonized attraction to traps when mixed with the pheromone [25]. While these examples demonstrate that formates can possess biological activity and in some cases are able to successfully mimic aldehydes, it appears that this is not the case in C. valdiviana. Considering that the overall chain length and the position and geometry of the double bonds were maintained in the formate analog, these results suggest a predominant importance of the formyl group of the natural aldehyde in the interaction of the pheromone with the respective antennal receptor. Due to the lack of biological activity found in the present field test, it appears that it will not be possible to replace the aldehyde pheromone by its formate analog in pest control methods.

\section{CONCLUSIONS}

The pheromone analog (5Z,8Z)-5,8-tetradecadienyl formate was synthesized by using standard organic chemistry reactions. In field tests with this compound, no biological activity towards males of Chilecomadia valdiviana was observed.

\section{ACKNOWLEDGEMENTS}

Financial support from Fondo Nacional de Desarrollo Científico y Tecnológico (grant 1140779 to JB) is gratefully acknowledged. HH thanks Comisión Nacional de Investigación Científica y Tecnológica for a doctoral fellowship (21130375).

\section{REFERENCES}

[1] A. Butenandt, R. Beckmann, D. Stamm, E. Hecker, Z. Naturforsch. 14b, 283, (1959)

[2] A. El-Sayed, The Pherobase: Database of Pheromones and Semiochemicals. http://www.pherobase.com, accessed 25.9.2017

[3] P. Witzgall, P. Kirsch, A. Cork, J. Chem. Ecol., 36, 80, (2010)

[4] M. Renou, A. Guerrero, Ann. Rev. Entomol., 45, 605, (2000)

[5] A. Angulo, T. Olivares, Bosque, 12, 67 (1991)

[6] A. Angulo, T. Olivares, Lepidoptera Novae 1, 119, (2008)

[7] P. Gentili, Rev. Chil. Hist. Nat. 61, 191, (1988)

[8] J.G. Petersen, Anales del Instituto de la Patagonia, 18, 51, (1988)

[9] J. Artigas, Entomología Económica. Insectos de interés agrícola, forestal, médico y veterinario Vol. 2. Ediciones Universidad de Concepción, Chile, 1994, pp. 479-486

[10] L. Cerda, P. Lewis in S. Barros, J. Prado, C. Alvear, eds., Actas Simposio Los Eucaliptos en el Desarrollo Forestal de Chile. Instituto Forestal, Santiago, 1993; pp. 339-353

[11] L. Cerda, A. Angulo, A. Durán, T. Olivares in A. Baldini, L. Pancel, eds., Agentes de daño en el bosque nativo. Editorial Universitaria, Santiago de Chile, 2000; pp. 201-281

[12] E. Prado, Artrópodos y sus enemigos naturales asociados a plantas cultivadas en Chile. Boletín Técnico $\mathrm{N}^{\circ}$ 169, Instituto de Investigaciones Agropecuarias, La Platina, 1991

[13] R. Ripa, P. Larral, Manejo de plagas en paltos y citricos. Colección 
Libros INIA No 23, La Cruz, Chile, 2008

[14] J.T. Kliejunas, B.M. Tkacz, H.H. Burdsall Jr, G.A. Denitto, A. Eglitis, D.A. Haugen, W.E. Wallner, Pest risk assessment of the importation into the United States of unprocessed Eucalyptus logs and chips from South America. Gen. TeC. Rep. FPL-GTR-124. Madison, WI: U.S. Department of Agriculture, Forest Service, Forest Products Laboratory, 2001

[15] H. Herrera, W. Barros-Parada, M.F. Flores, W. Francke, E. FuentesContreras, M. Rodriguez, F. Santis, P.H.G. Zarbin, J. Bergmann, J. Chem. Ecol. 42, 908, (2016)

[16] S.L. Lapointe, W. Barros-Parada, E. Fuentes-Contreras, H. Herrera, T. Kinsho, Y. Miyake, R.P. Niedz, J. Bergmann, J. Chem. Ecol. 43, (2017), in press

[17] E.R. Mitchell, J.H. Tumlinson, A.H. Baumhover, J. Chem. Ecol. 4, 709, (1978)
[18] K. Mori, H. Watanabe, M. Fujiwhara, S. Kuwahara, Liebigs Ann. Chem. $1257,(1990)$

[19] J.L. Todd, J.G. Millar, R.S. Vetter, T.C. Baker, J. Chem. Ecol., 18, 2331, (1992)

[20] N. Miyashita, A. Yoshikoshi, P.A. Grieco, J. Org. Chem. 42, 3772, (1977)

[21] E. J. Corey, G. Schmidt, Tetrahedron Lett. 399, (1979)

[22] G.A. Wiley, R.L. Hershkowitz, B.M. Rein, B.C. Chung, J. Am. Chem. Soc., 86, 965, (1964)

[23] H.J. Bestmann, W. Stransky, O. Vostrowsky, Chem. Ber. 109, 1694, (1976)

[24] E.R. Mitchell, M. Jacobson, A.H. Baumhover, Envir. Entomol., 4, 577, (1975)

[25] W. Francke, S. Franke, J. Bergmann, T. Tolasch, M. Subchev, A. Mircheva, T. Toshova, A. Svatos, B. Kalinova, Z. Karpati, G. Szöcs, M. Toth, Z. Naturforsch. 57c, 739, (2002) 